\title{
EXPERIMENTAL INVESTIGATION OF ENHANCING THE COP OF VCRS SYSTEM BY USING COOLING TOWER
}

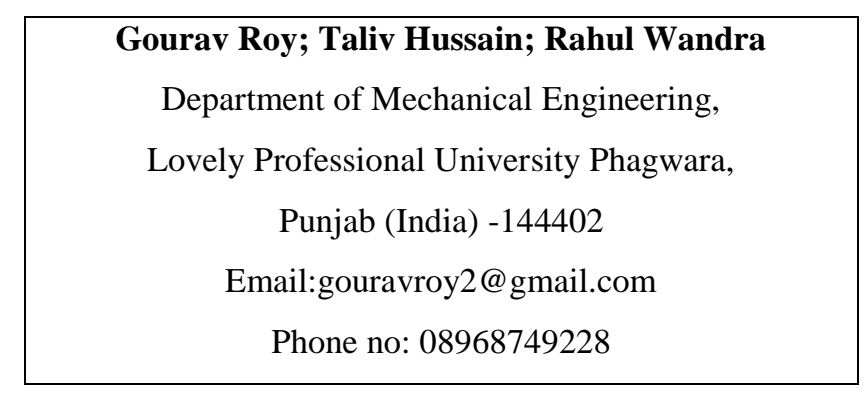

\begin{abstract}
During the hot days when sun light at its maximum intensity VCRS (water cooled condenser) consume more power to cool down the substance and also consume lots of water. As the standard VCRS (water cooled condenser) approach practical limits, experimental modification should be performed to increase the system efficiency and capacity. One possible means to increase the COP of VCRS (water cooled condenser) is by using cooling tower consist of single cellulose pad on it. In this paper experimental investigation in order to enhancing the COP of VCRS (water cooled condenser) that utilize single cellulose pad as the filling material of cooling tower. The cooling tower performance is improved due to good water wet ability of cellulose pad that cause a uniform water circulation over the entire surface of pads and a perfect contact between water and cooling air. A VCRS has been built with water cooled condenser. In first case water cooled condenser is used at ambient temperature $29^{\circ} \mathrm{C}$ and $32^{\circ} \mathrm{C}$. There is increase in COP 4.69 to 4.67. Similarly in second case water cooled condenser is attached with cooling tower with single pad at an ambient temperature $29^{\circ} \mathrm{C}$ and $32^{\circ} \mathrm{C}, \mathrm{COP}$ increase from 4.93 to 4.68 .
\end{abstract}

Keywords-Air cooled condenser, Water cooled condenser, vapour compression refrigeration system, evaporative cooling pad.

\section{Nomenclature-COP Coefficient of performance}

h1 Enthalpy of refrigerant at inlet of compressor in $\mathrm{kj} / \mathrm{kg}$

h2 Enthalpy of refrigerant at exit of compressor in $\mathrm{kj} / \mathrm{kg}$

h3 Enthalpy of refrigerant at exit of the condenser $\mathrm{kj} / \mathrm{kg}$

h4 Enthalpy of refrigerant at entry of evaporator in $\mathrm{kj} / \mathrm{kg}$ mref Mass flow rate of refrigerant

Qr Cooling effect

Wc Compressor work

T1 Suction temperature of refrigerant into the compressor

T2 Discharge temperature of refrigerant into the compressor

T3 Condenser outlet temperature of refrigerant

T4 Outlet temperature of refrigerant from capillary tube

\section{Inlet current \\ V Inlet voltage}

\section{I.INTRODUCTION}

The fruit of development would not reach to the common man until energy reached the last household of the country. In RAC the special focus is given on VCRS in order to improve the performance and cooling capacity of a system. The refusal to accept anything without testing and trail, the capacity to change previous conclusion in the face of new evidence, the reliance on observe fact this all is necessary. Special emphasis will be placed on equity in development of VCRS system, so that the benefit of technological growth reaches the majority of population, leading to an improved quality of life forever citizen of country.

Our main focus how to increase the COP of VCRS system .Cooling tower is one of the appropriate method to improve the performance of water cooled condenser.In order to further improving COP, use cellulose pad within the cooling tower which helps to increase the COP. For two different ambient temperature $29^{\circ} \mathrm{C}$ and $32^{\circ} \mathrm{C}$ COP varies from 4.96 to 4.67 at water cooled condenser.Similarly in next case cooling tower with single pad at $29^{\circ} \mathrm{C}$ and $32^{\circ} \mathrm{C}$ respectively COP changes from 4.93 to 4.68 .

\section{II.LITERATURE SURVEY}

Fouda and Melikyan et al. [1] A simplified mathematical model was used to discuss the heat and mass transfer between the air and water in a direct evaporative cooler. A comparison between the model results and the experimental results was presented. The results indicate that during a steady state condition, the cooling efficiency is decreased by increasing the inlet frontal air velocity, and increased by increasing the pad thickness. This is because the contact surface between water and air is increased.

S.S. Hu, B.J. Huang et al. [2] conducted an experimental investigation on a split air conditioner having water cooled condenser. They developed a simple watercooled air conditioner utilizing a cooling tower with 
ELK

\section{Asia Pacific Journals}

cellulose pad filling material to cool the water for condensing operation. The experimental investigation verified that the water-cooled condenser and cooling tower results in decreasing the power consumption of the compressor.

Sreejith K et al. [3] Heat can be recovered by using the water-cooled condenser and the system can work as a waste heat recovery unit. The recovered heat from the condenser can be used for bathing, cleaning, laundry, dish washing etc. The modified system can be used both as a refrigerator and also as a water heater. Therefore by retrofitting a water cooled condenser it produce hot water and even reduce the utility bill of a small family. In this system the water-cooled condenser is designed as a tube in tube heat exchanger of overall length of $1 \mathrm{~m}$. It consists of an inlet for the cooling water and an exit for collecting the hot water. The hot water can be used instantly or it can be stored in a thermal storage tank for later use.

Adarsh Mohan Dixit, Aditya Desai, Akshay Vyas et al.[4] They made setup of 1.5 ton air conditioner was constructed and tested in the present study. The experimental results show the coefficient of performance (COP) reaches 8.03 that are higher than the standard value (5.98) of those conventional residential split air conditioners.

W.L Lee et al. [5] performed the experiments to study the effect of water cooled air conditioning systems in residential building in Hong Kong with outdoor at $35^{\circ} \mathrm{C}$ DBT. The test results showed that COP was increased by $14-20 \%$ as compared to the aircooled condenser which reduced the peak load in the month of July by $27 \%$. Later in 2008 he also studied the performance of domestic water cooled air conditioning using tube-in-tube helical heat exchanger condenser. The outdoor condition was $33^{\circ} \mathrm{C}$ DBT and $68 \% \mathrm{RH}$. The mass flow rate of tap water was $5-81 \mathrm{t} / \mathrm{min}$. An increase of $12-20 \%$ in COP was recorded.

S.S.Hu et al. [6] studied the split type residential water cooled air conditioning system using cellulose pad to remove heat of the water immersed condenser. The experiment was done at an ambient condition of $35^{\circ} \mathrm{C}$ DBT and $27^{\circ} \mathrm{C}$ WBT, air velocity of $1.7 \mathrm{~m} / \mathrm{sec}$ and water flow rate of $5.11 \mathrm{t} / \mathrm{min}$. The COP was increased from 2.96 to 3.45 which is an increase of $17 \%$.

\section{EXPERIMENTAL SETUP}

A VCRS system is build which consists of a single stage with the basic components i.e. evaporator, compressor, expansion device and condenser. A tank of ten liters is built and condenser is put in that tank and tank is filled with water as shown in the figures. A water circulation system including a small pump (15Watt), is put in the tank and the outlet of pump is connected to the cooling tower because the function of the pump is to transfer the hot water from the condenser tank in to the cooling tower where it is cooled a bucket. Water circulation rate is constant for all tests. Hot ambient water is passes over the evaporative media pad of the cooling tower and gets cooled and cooled water is collected in the tank which is located in the below of the cooling tower in the cooling tower tank second pump is installed, function of this pump is to transfer the cooled water from the cooling tower tank in to the condenser tank, it become a closed cycle in which hot water and cold water circulate. In cooling tower evaporative pad of thickness 2 inch is used.

Here the capillary tube is used, made up of a copper tube of very small diameter. Capillary tube used as expansion device. The evaporator is used to reduce the pressure, dissipating heat and making liquid refrigerant to much cooler.

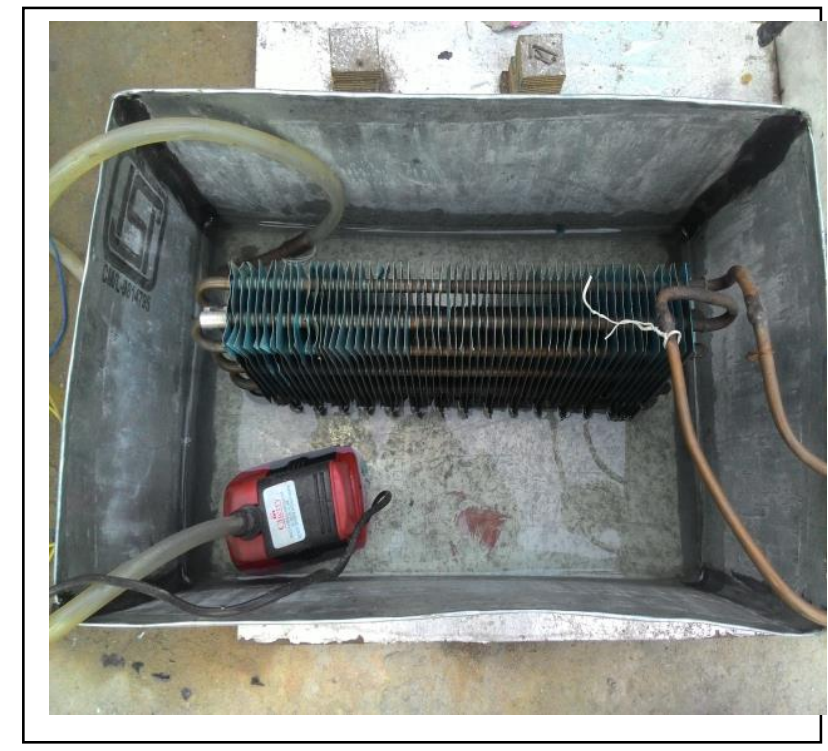

Fig.1 Water Cooled condenser with cooling tower

After calculated different parameter by using water cooled condenser, now condenser is attached to cooling tower as shown in (Fig.2). 
ELK

Asia Pacific Journals

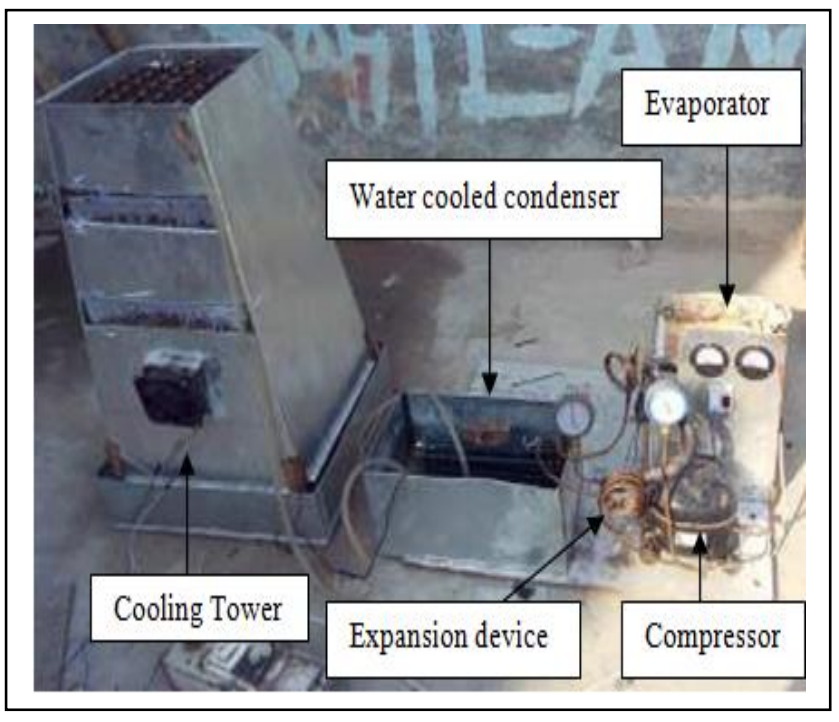

Fig.2 Water Cooled condenser with cooling tower

Here the cooling tower performance is improved due to good water wet ability of cellulose pad that cause a uniform water circulation over the entire surface of pad and a perfect contact between water and cooling air.

The cooling tower cool the warm water discharged from the condenser and feed the cooled water back to the condenser. They, thus reduce the demand of cooling water in system. (Fig 3) Represent the close view of cooling tower which consist of cellulose pad.

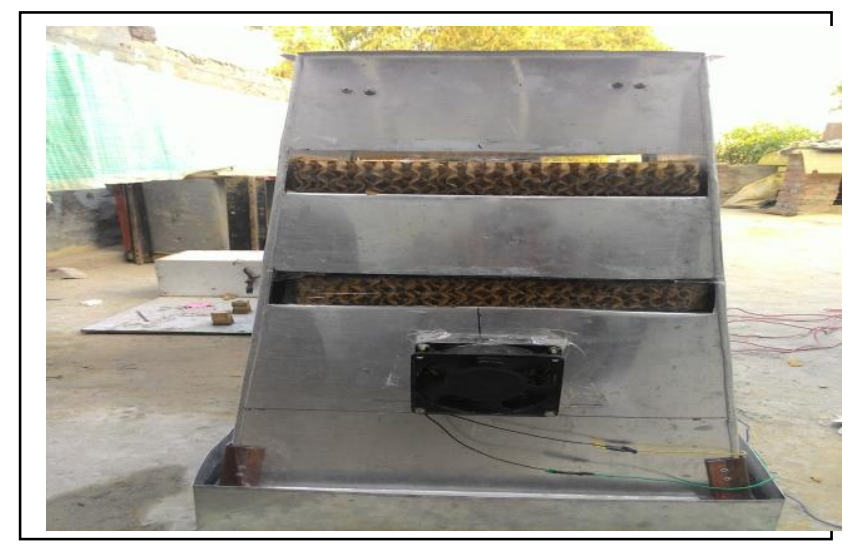

Fig 3:Cooling Tower
ELK Asia Pacific Journals - Special Issue

ISBN: 978-81-930411-4-7

\begin{tabular}{|c|c|c|c|c|c|}
\hline \multirow[t]{2}{*}{ PARAMETERS } & \multirow[t]{2}{*}{ UNIT } & \multicolumn{2}{|c|}{$\begin{array}{l}\text { Water Cooled } \\
\text { condenser }\end{array}$} & \multicolumn{2}{|c|}{$\begin{array}{l}\text { Water cooled } \\
\text { condenser with } \\
\text { cooling tower }\end{array}$} \\
\hline & & $\begin{array}{l}\text { At } \\
29^{\circ} \mathrm{C}\end{array}$ & $\begin{array}{l}\text { At } \\
\text { 32 }^{\circ} \mathrm{C}\end{array}$ & $\begin{array}{l}\text { At } \\
29^{\circ} \mathrm{C}\end{array}$ & $\begin{array}{l}\text { At } \\
32{ }^{\circ} \mathrm{C}\end{array}$ \\
\hline Suction Pressure & Psi & 12 & 12 & 5 & 5 \\
\hline $\begin{array}{l}\text { Discharge } \\
\text { Pressure }\end{array}$ & Psi & 160 & 160 & 148 & 148 \\
\hline $\begin{array}{l}\text { Condenser Inlet } \\
\text { Temperature }\end{array}$ & $\begin{array}{l}\text { Degree } \\
\text { Celsius }^{\circ} \mathrm{C}\end{array}$ & 36.2 & 38.4 & 35.2 & 37.4 \\
\hline $\begin{array}{l}\text { Condenser Outlet } \\
\text { Temperature }\end{array}$ & $\begin{array}{l}\text { Degree } \\
\text { Celsius }{ }^{\circ} \mathrm{C}\end{array}$ & 29.1 & 31.3 & 28.1 & 30.3 \\
\hline $\begin{array}{l}\text { Compressor Inlet } \\
\text { Temperature }\end{array}$ & $\begin{array}{l}\text { Degree } \\
\text { Celsius }{ }^{\circ} \mathrm{C}\end{array}$ & 10.2 & 12.2 & 19.2 & 21.2 \\
\hline $\begin{array}{l}\text { Compressor Outlet } \\
\text { Temperature }\end{array}$ & $\begin{array}{l}\text { Degree } \\
\text { Celsius }{ }^{\circ} \mathrm{C}\end{array}$ & 43.1 & 45.1 & 35.3 & 37.3 \\
\hline $\begin{array}{l}\text { Evaporator Inlet } \\
\text { Temperature }\end{array}$ & $\begin{array}{l}\text { Degree } \\
\text { Celsius }{ }^{\circ} \mathrm{C}\end{array}$ & 20.1 & 19.4 & 21.3 & 20.5 \\
\hline $\begin{array}{l}\text { Evaporator Outlet } \\
\text { Temperature }\end{array}$ & $\begin{array}{l}\text { Degree } \\
\text { Celsius }^{\circ} \mathrm{C}\end{array}$ & -16.2 & -15.2 & -18.1 & $\begin{array}{l}-17.4 \\
\end{array}$ \\
\hline Current & I & 0.68 & 1.42 & 0.63 & 1.23 \\
\hline Voltage & $\mathrm{V}$ & 210 & 200 & 210 & 200 \\
\hline
\end{tabular}

Table 1: Result of the experiment of water cooled condenser and water cooled condenser with cooling tower

The given experiment was carried out at two different ambient temperature $29{ }^{\circ} \mathrm{C}$ and $32{ }^{\circ} \mathrm{C}$ respectively. In first case we calculate the COP of system with water cooled condenser and then same water cooled condenser is attached to cooling tower. While performing the experiment refrigerant and air remained constant in order to achieve steady state also current and voltage is constant for both the ambient temperature. 


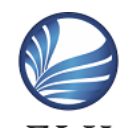

ELK

Asia Pacific Journals

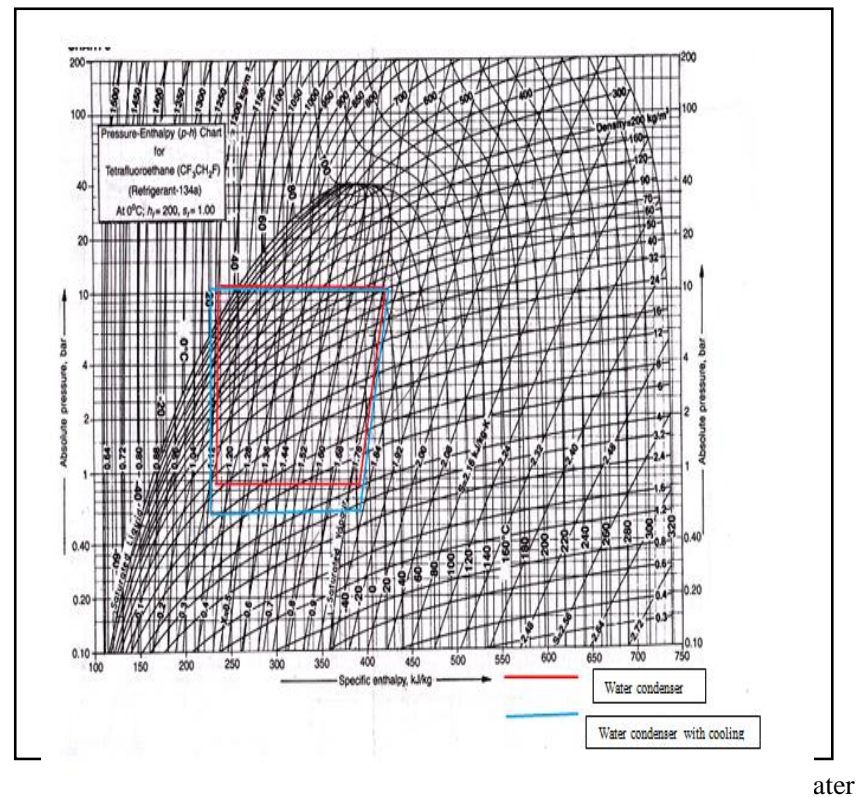

cooled condenser with cooling tower at $29^{\circ} \mathrm{C}$

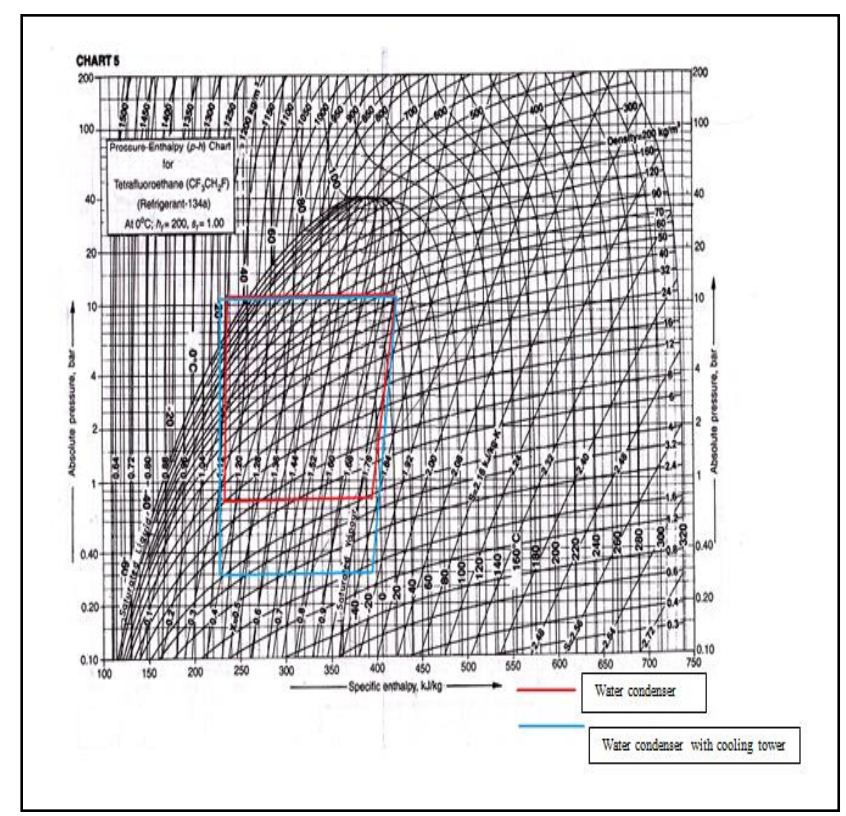

Fig 5: Pressure-Enthalpy diagram for water cooled condenser and water cooled condenser with cooling tower at $32^{\circ} \mathrm{C}$

\section{CAlCulation And Result}

While performing the experiment, the result obtained. Based on this result thermodynamic properties of refrigerant $\mathrm{R} 134 \mathrm{a}$ are obtained at the different point of the system. In
ELK Asia Pacific Journals - Special Issue

ISBN: 978-81-930411-4-7

order to calculate the enthalpy, using the P-h chart of the refrigerant R134a and we are getting different parameter at air cooled condenser and water cooled condenser attached with cooling tower.

a. Compressor Work Wc $=\mathrm{V} * \mathrm{I}=m_{\text {ref }} *(\mathrm{~h} 2-\mathrm{h} 1)$

b. Mass flow rate of refrigerant $m_{r e f}=\frac{\text { We }}{(h 2-h 1)}$

c. Cooling effect produced $\mathrm{Qr}=m_{\text {ref }} *(\mathrm{~h} 1-\mathrm{h} 4)$

d. $\mathrm{COP}=\frac{\mathrm{Q} r}{\mathrm{Wc}}$

Where,

h1 = enthalpy of refrigerant at inlet of compressor in $\mathrm{kj} / \mathrm{kg}(1)$

$\mathrm{h} 2=$ enthalpy of refrigerant at exit of compressor in $\mathrm{kj} / \mathrm{kg}$ (2)

$\mathrm{h} 3=$ enthalpy of refrigerant at exit of the condenser $\mathrm{kj} / \mathrm{kg}$ (3)

h4 = enthalpy of refrigerant at entry of evaporator in $\mathrm{kj} / \mathrm{kg}(4)$

\begin{tabular}{|c|c|c|c|c|}
\hline \multirow{2}{*}{ Parameter } & \multicolumn{2}{|c|}{$\begin{array}{c}\text { Water Cooled } \\
\text { condenser }\end{array}$} & \multicolumn{2}{c|}{$\begin{array}{c}\text { Water Cooled } \\
\text { condenser with } \\
\text { cooling tower }\end{array}$} \\
\cline { 2 - 5 } & $29^{\circ} \mathrm{C}$ & $32^{\circ} \mathrm{C}$ & $29^{\circ} \mathrm{C}$ & $32^{\circ} \mathrm{C}$ \\
\hline COP & 4.69 & 4.67 & 4.93 & 4.68 \\
\hline Compressor Work & 142 & 280 & 132.6 & 246 \\
\hline
\end{tabular}

Table 2: Result of the experiment at ambient air temperature $29^{\circ} \mathrm{C}$ and $32^{\circ} \mathrm{C}$

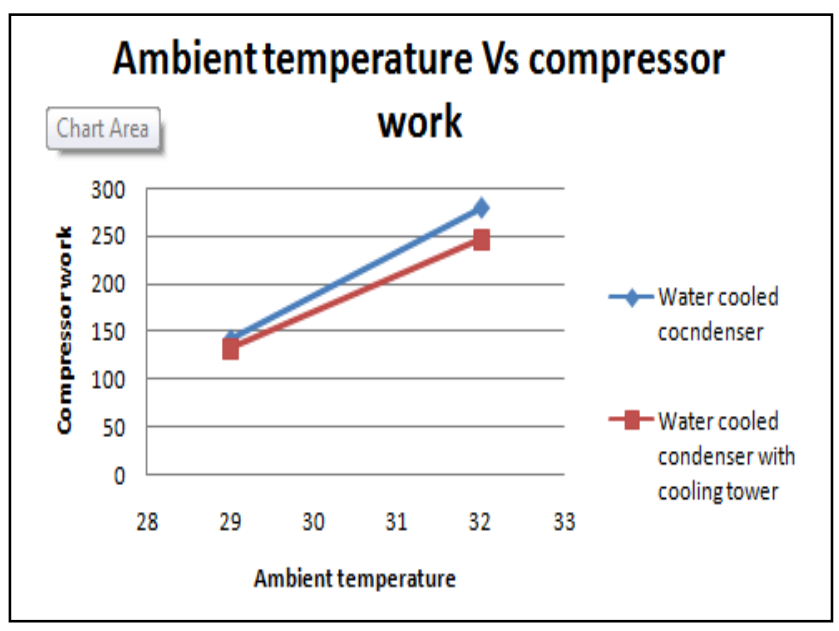


ELK

Asia Pacific Journals

Graph 1: Compressor work variation with ambient temperature

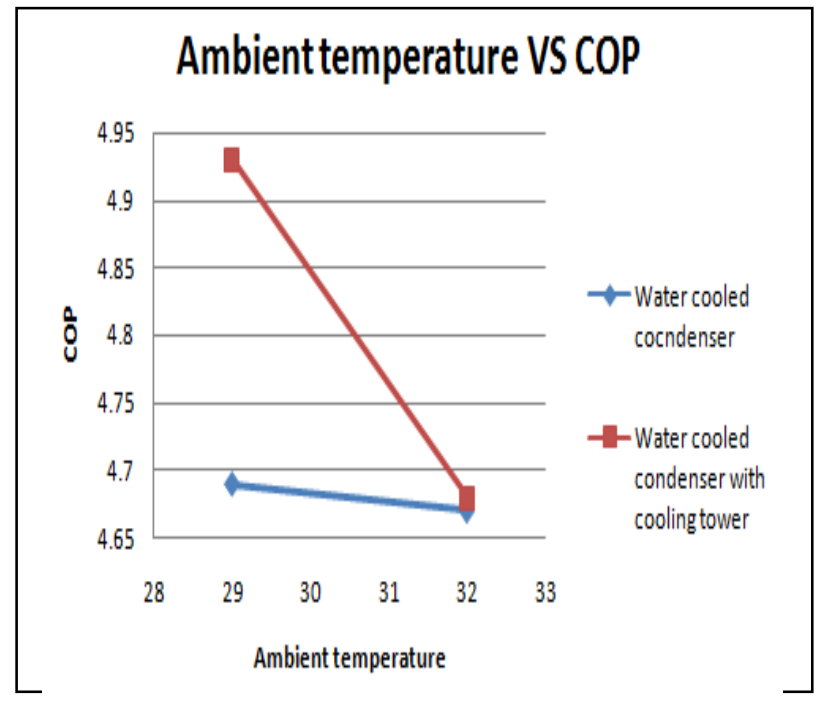

Graph 2: cop variation with ambient temperature

The above two graph represent variation of ambient temperature with compressor work and COP. As the ambient temperature increase from $29^{\circ} \mathrm{C}$ to $32^{\circ} \mathrm{C}$ the compressor work goes on increase in both case water condenser and water condenser with cooling tower. Similarly the ambient temperature increase COP of system decrease further decrease in cooling capacity.

\section{CONCLUSION}

The cooling tower concept is simple and easy to install in normal water cooled VCRS system. Cooling tower is used to cool down the hot water from condenser which is circulated with help of water pump. This cool water collect at the bottom of cooling tower from where it is again circulated at the water condenser where it act as cooling medium. From our experiment there is increase in COP of the system as we move from simple water condenser to water condenser with cooling tower which at $29^{\circ} \mathrm{C}$ is $5.11 \%$ and at $32^{\circ} \mathrm{C}$ is $0.21 \%$. Also as the ambient temperature is increase compressor work is also increase in both the cases. AT $29^{\circ} \mathrm{C}$ compressor changes $7.02 \%$ and $32^{\circ} \mathrm{C}$ it is $13.82 \%$ when we cooling tower.

\section{REFERENCES}

[1] A.Fouda and Z. Melikyan.A simplified model for analysis of heat and mass transfer in a direct evaporative cooler. Appl. Therm. Eng. 2011; 31: 932-936.

[2] S.S. Hu, B.J. Huang, "Study of a high efficiency residential split watercooled air conditioner", Applied Thermal Engineering 25 (2005) 15991613.

[3] Experimental Investigation of A Domestic Refrigerator Having water cooled condenser using various compressor oils, Sreejith K, Assistant Professor, Dept.Of Mechanical.

[4] Improving efficiency of air conditioner by cellulose pad/International journal of engineering science \& humanities ISSN 2250-3552.

[5] Lee WL, Yik FWH. "A framework for formulating a performance based incentive rebate scale for the demand side energy management scheme for commercial buildings in Hong Kong" Application Energy, 2002;73:139-66 